\title{
Archaeological excavations and reconstruction of Ahu Tongariki - Easter Island
}

\section{Claudio Cristino}

\section{Filiación}

Arqueólogo y Antropólogo del Instituto de Estudios Isla de Pascua y Departamento de Urbanismo de la Facultad de Arquitectura y Urbanismo de la Universidad de Chile, especialista en Polinesia, área en la cual ha trabajado y residido desde 1976. Actualmente está encargado de la sede que la Universidad de Chile mantiene en Isla de Pascua.

\section{Patricia Vargas}

\section{Filiación}

Arqueóloga y Antropóloga del Instituto de Estudios Isla de Pascua y Departamento de Urbanismo de la Facultad de Arquitectura y Urbanismo de la Universidad de Chile, especialista en Polinesia, área a la cual ha estado vinculada desde 1976. Desde hace una década, es la Directora del Instituto en la Facultad de Arquitectura y Urbanismo de la Universidad de Chile en Santiago.

\begin{abstract}
This paper is a brief summary of the presentation at one of the sessions and a field visit to Ahu Tongariki during the Second International Congress on "Easter Island and Eastern Polynesian Archaeology" held at Hanga Roa, Easter Island in October 1996. Final results of this on-going research project and full presentation of the archaeological data, chronology and conservation and reconstruction procedures of the site await completion. Most of the preliminary conclusions presented, regarding the character and archaeological evolution of the monument, should be considered with reservation, although we think that they will not significantly change after the data analysis of this profoundly disturbed site are completed.
\end{abstract}

\section{Key words}

Easter Island, archeology, restoration, ahu Tongariki, Isla der Pascua.

\section{Resumen}

Este artículo es un breve resumen de la presentación en una de las sesiones y visita a terreno a Ahu Tongariki, durante el Segundo Congreso Internacional de Arqueología de Isla de Pascua y Polinesia Oriental, realizado en Hanga Roa, Isla de Pascua en octubre de 1996. Los resultados finales de este proyecto aún en desarrollo y una exposición completa de la data arqueológica, cronología y procedimientos de reconstrucción (restauración) y conservación, están en proceso de ser completados. La mayor parte de las conclusiones preliminares acerca del carácter y evolución arqueológica del monumento, deben ser consideradas con reserva, aun cuando pensamos que ellas no cambiarán significativamente una vez completados los análisis de este sitio profundamente alterado. 


\section{Palabras Claves}

Isla de Pascua, arqueología, restauración, ahu Tongariki, Easter Island.

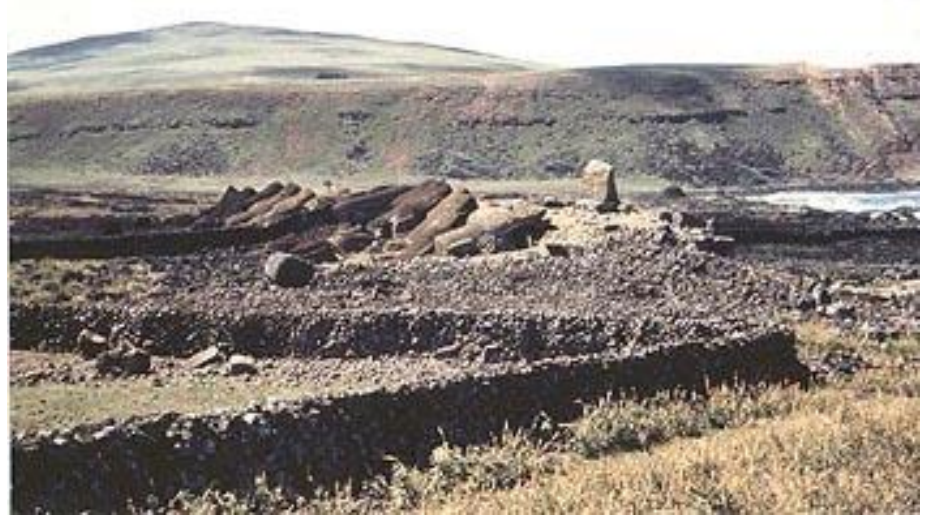

Figura 1. OArchivo Instituto Isla de Pascua, F.A.U. Universidad de Chile.

Hanga Nui Bay, on the eastern end of the southeast coast of Easter Island, is currently the focal point of research in an intensively studied archaeological area that extends from the plains at the foot of the southwest slopes of the Poike Peninsula. The study area is a transect which crosses the island from coast to coast in a North to South axis from Hanga Nui to Mahatua on the East and from Motu Nao to an area close to Te Peka Peka to the West.

This transect, included within quadrangles 13, 14, 20, 21 and 31 of the island's general archaeological survey, has a maximum linear distance of approximately seven kilometers and a total area of approximately twelve square kilometers, occupying most of the historically known territory of the Tupahotu mata or 'tribe'. Within this transect the highest densities of prehistoric sites and features and some of the largest and most specialized activity areas and ceremonial architecture occur. Among these are Ahu Tongariki, the moai quarries of Rano Raraku, and important ceremonial centers of the northeast coast: Mahatua, Ra'ai, Heki'i and Te Pito Kura (Paro).

Close to three hundred ceremonial or burial structures, classed in several distinctive types are known and recognized as ahu on the whole island. Of these, a smaller number are large, complex, raised, rectangular platforms, with or without wings, ramps and associated open courts or 'plazas'. Most of this ahu supported multi-ton monolithic statues (moai) of volcanic tuff.

Ahu and moai, symbols of the prestige and status of a lineage or tribe, raised to worship deified ancestors, are the most conspicuous features of the archaeological 
landscape. A typological analysis of radiocarbon-dated structures indicates that the ahu and statues complex represent -in the words of William Mulloy one of our mentors-an "unbroken chronological progression such as might be expected from the architectural reflection of the activities of a single continuously developing society." Based upon these data the final structure at $A h u$ Tongariki represents the type of monuments constructed during the mid- to late part of the ahu-moai sequence.

A combination of archaeological data, oral traditions, ethnography, historical documents and architectural analysis, suggest that ahu were destroyed and/or deeply modified as the result of profound sociopolitical and religious changes that occurred in late prehistoric times. This may have been a pan-island revolution, triggered by a generalized degradation of the environment, critical maximum levels of population and a complex set of 'negative' variables that altered the delicate equilibrium of the whole system and resulted in cultural collapse. Several other specialists indicate that most ahu and moai were deeply altered as a direct consequence of intertribal warfare.

Most scholars support the idea that the destruction, toppling of the statues and important changes in function of the ceremonial and religious centers, occurred after $1500 \mathrm{AD}$ and continued well into the post-contact period. After the toppling of the statues, most of these ruins continued to be used as burial sites, deeply altering the original structure, until the conversion of the population to Catholicism in the second half of the XIX century, when they were finally deserted.

Europeans first saw Easter Island in 1722. Members of the Dutch expedition led by Jacob Roggeveen, that discovered the island, described some monuments $(a h u)$ and statues still standing near his anchorage off the North coast, probably at Hanga Ho'onu. James Cook in 1774 and La Pérouse in 1786 gave similar accounts. As stated elsewhere by explorers and visitors, during the XVIII and early XIX centuries most ahu in other sections of the island looked like "old" ruins and few statues were seen standing. All of them were down by mid-XIX century.

The drastic reduction of pre-contact population, the subsequent dramatic post contact depopulation -consequence of slave raids and introduced diseases in the 1860's and the conversion of the survivors to Catholicism, provoked the abandonment of many of the ancient tribal territories, including the Hanga Nui area. This tragic sequence of late prehistoric and historic events was accelerated by the installation of European and Chilean settlers in late XIX century, and the forced concentration of the remaining population on the West coast of the island, when all the tribal territories were definitely deserted.

Ahu Tongariki was the largest ceremonial structure ever built on Easter Island. In terms of size, plan and the number of statues, it represents the apogee in the development of the so-called 'image $a h u$ ', most of which were built in a period of approximately five or six hundred years between circa 1000-1500 AD. This monument is one of the most spectacular expressions of prehistoric megalithic ceremonial architecture in the entire Polynesian culture area. 
With a central platform close to one hundred meters long and two lateral extensions, or wings, associated with frontal access ramps, this ahu originally had a total length of approximately two hundred and twenty meters. The average height of the massive seaward wall was over four meters and used more than eight hundred crude and irregularly fitted basalt blocks.

During its final phase of construction and function as a ceremonial altar, the central platform of ahu Tongariki supported fifteen monolithic statues of volcanic tuff (moai), carved at and transported from the quarries of Rano Raraku volcano, about one kilometer to the Northwest. The ahu Tongariki had heights that ranged from more than five to nine meters. Average weight was over forty metric tons, with the largest statue, placed near the central section of the platform, weighing eighty-eight metric tons. With the statues raised on top of the platform and crowned by large cylinders of red scoria (pukao), the monument had the impressive height of close to fourteen meters.

In 1770 the Spaniards under González y Aedo circumnavigated the island using small craft and described and mapped several coves and bays, while looking for safe anchorage and landing places. One of these groups headed by Lángara, entered Hanga Nui bay close to the coast and did not describe inhabitants, monuments or erected statues. If ahu Tongariki was still functioning as a ceremonial altar at the time, they could not have failed to notice this enormous monument and the gigantic statues that would certainly be visible from a long distance. It is reasonable to assume that ahu Tongariki was in ruins and presumably abandoned by 1770 and probably well before Roggeveen's discovery of the island. The site continued to be used for burial well into the XIX century.

Between circa 1870 and 1960 the ruined ahu Tongariki remained relatively intact. Although the ranching operations of late XIX and early XX centuries used the area to concentrate sheep, destroying one of the wings and using other material from the platform to build stone fences and enclosures to divide the land. Photographs taken between 1886 and 1959, descriptions, drawings and sketch maps of several scholars and visitors to the island, collected by the authors, show with great detail the characteristics and conditions of the original monument at that time. Even in its ruined state Tongariki was fairly well preserved and was one of the most remarkable monuments and complex archaeological sites of the island.

On May 22, 1960 one of the largest earthquakes ever recorded, destroyed most of the central and Southern regions of Chile, 3700 kilometers to the East of Easter Island. The earthquake caused a major tsunami or tidal wave that crossed the South Pacific Ocean in a few hours and hit the eastern and southeastern coasts of the island. The devastation of the tidal wave continued as far as Japan and Hawaii.

Various estimations and calculations indicate that a wall of water, over eight meters high, reached Easter Island and entered the low bay of Hanga Nui and surrounding lowlands to the base of Rano Raraku volcano. It frontally impacted the four meters high seaward wall of the monument, completely destroying the main platform to its foundations and spreading the remains over an area of more than four hectares. 


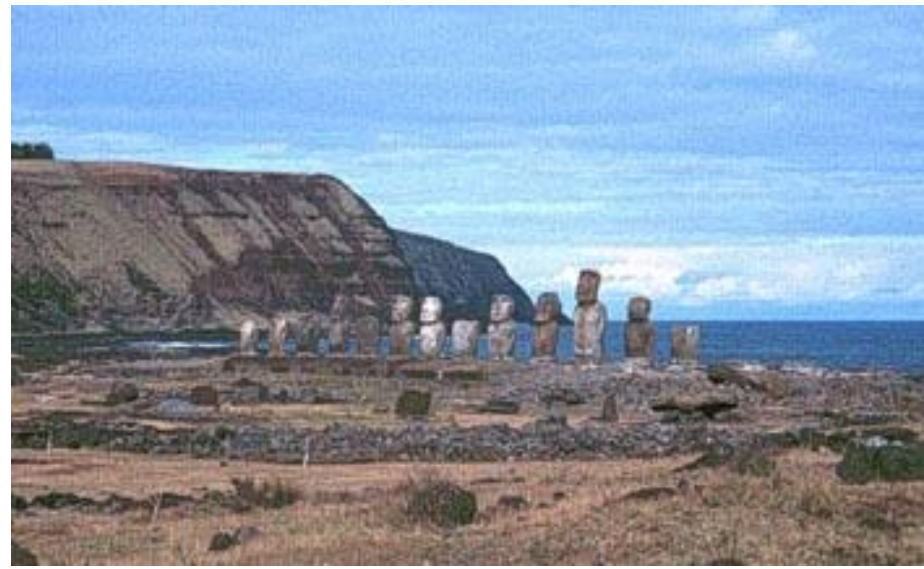

Figura 2. @Archivo Instituto Isla de Pascua, F.A.U. Universidad de Chile.

Some of the fifteen statues were pushed more than one hundred and fifty meters inland and were broken and covered by thousands of tons of the ahu walls and fill. When the water retreated, it had deeply altered or destroyed most of the remaining monument. The tsunami left in situ only a small portion of the central section of the ahu ramp and the fragmentary and obliterated remains of the wall foundations of the main platforms and plaza pavements.

Before this event, the matrix of the ruined and abandoned ahu described historically, was a very complex and impressive archaeological deposit with a reconstructed calculated volume of 23,000 cubic meters above the post-occupation surface. Like many other monuments of its kind, it suggested the accumulated evidence of successive construction phases over time. Expansions of former ahu, recycling of earlier platforms, archaic types of statues and other evidence indicate continuous occupation and ceremonial religious, mortuary and sociopolitical activities at the site for approximately six to seven hundred years. In the opinion of several contemporary researchers, this evidence probably encompasses most of the prehistoric evolution of the island's culture.

As a result of the devastating destruction of the tsunami, it was reasonable to believe that this great monument was lost forever. Since 1960, many colleagues had the dream of "restoring" the monument, but the complexity, time, effort and costs of such a project labeled the idea as impossible. In 1979, the authors systematically surveyed that section of the island, mapped the ruins of the area with great detail and also thought that a restoration was not feasible with the means, technical experience, personal knowledge of the materials and levels of information available at that time.

In 1991, this situation radically changed, and even though it was not a research priority and other important work was in progress, we started to consider the extraordinary possibility of rebuilding Tongariki. The donation, by a Japanese company (Tadano) of funds and equipment required, in particular a large modern crane capable of handling some of the largest statues allowed serious consideration of this project. 
http://revistaurbanismo.vchile.cl

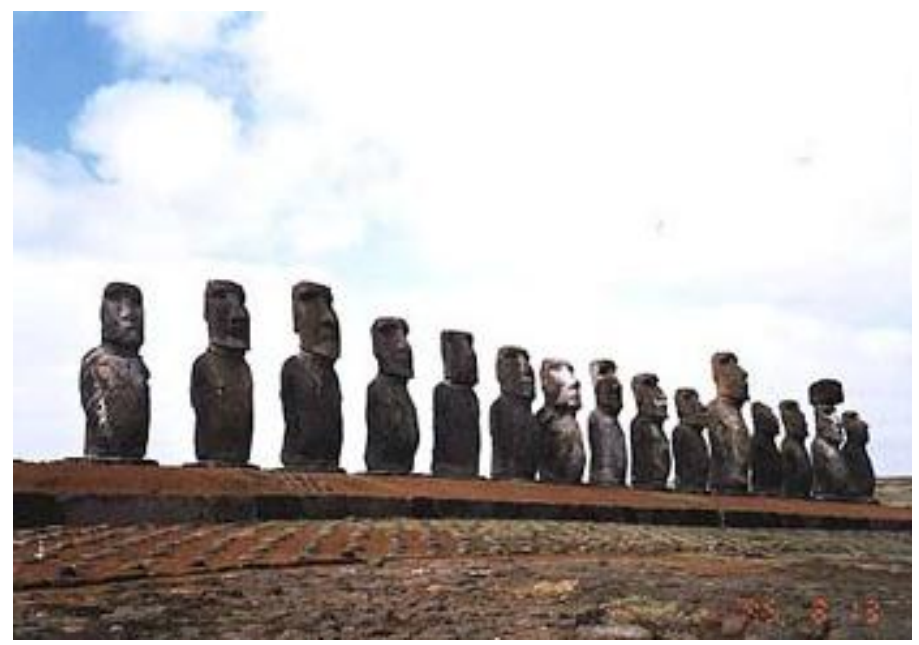

Figura 3. GArchivo Instituto Isla de Pascua, F.A.U. Universidad de Chile.

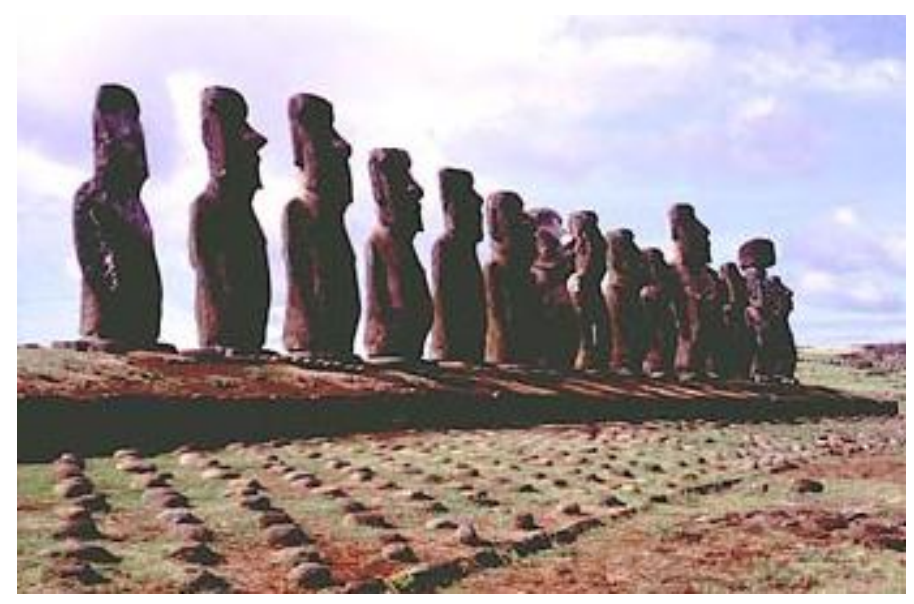

Figura 4. GArchivo Instituto Isla de Pascua, F.A.U. Universidad de Chile.

The feasibility of a realistic re-assemblage of the ruins was based and defined upon a detailed analysis of late XIX century and pre-1960 source data. Methodology included the study of the post-tsunami ruins and conventional subsurface archaeological excavations and the design of a computer-based reconstruction strategy using precision cartography, geomorphologic data, digital analysis and correction of historical photographs, drawings and three-dimensional modeling.

The main goal of this project was the reconstruction of an almost completely destroyed architectural monument. A significant finding of the archaeological work at Tongariki was that the whole ahu site and archaeological deposits contained within the matrix of the main structures, most of them by definition secondarily deposited, were completely 
http://revistaurbanismo.uchile.cl

destroyed to ground level by the tsunami of 1960. Sub-surface archaeological deposits were very limited or non-existent.

The structural remains of the ahu below the plaza's surface level showed a complex sequence of architectural expansions an ubiquitous recycling of components of several platforms and pavements and the use -as indicated above-of earlier types of statues as foundations, walls building blocks or fill material.

Except for a few artifacts, that are undoubtedly intrusive or secondarily deposited, very little was found in the trenches excavated down to the natural, pre-occupation surface through the massive fill (large rocks) of the ahu foundations and the interface of the artificially leveled area in front of the ahu. Only scant evidence came from a shallow layer $(<30 \mathrm{~cm})$ at the interface of the fill and the natural surface, indicating occupations or some human activity before the fill and leveling occurred. These remains pre-date most construction activity in the area.

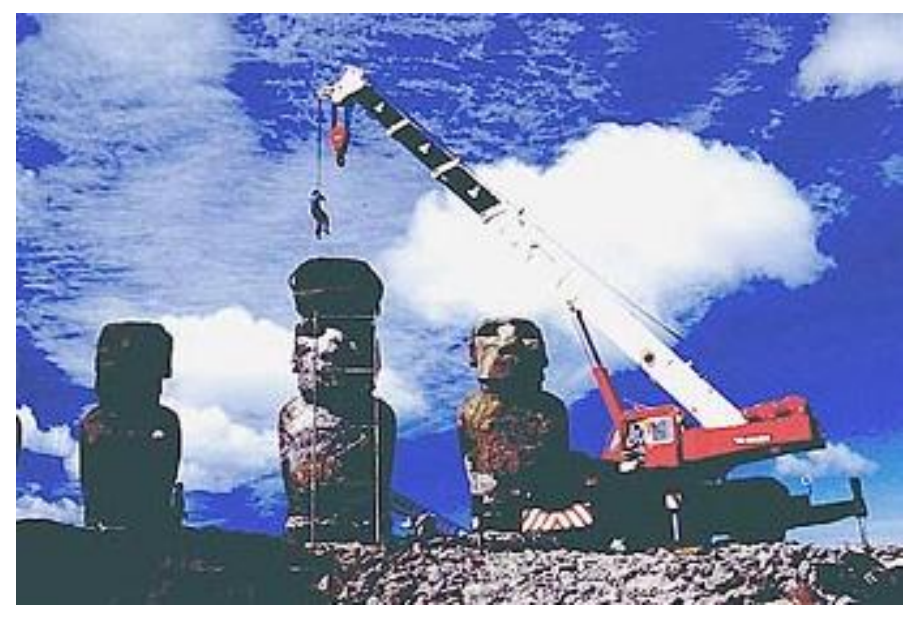

Figura 5. 9Archivo Instituto Isla de Pascua, F.A.U. Universidad de Chile. 
http://revistaurbanismo.vchile.cl

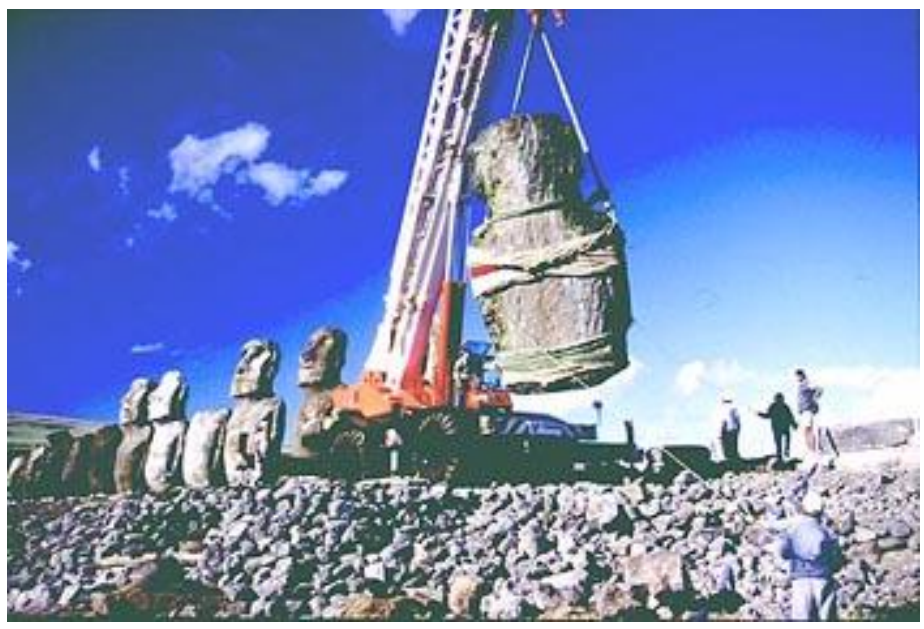

Figura 6. AArchivo Instituto Isla de Pascua, F.A.U. Universidad de Chile.

Thus, our current understanding of the chronology of the site can only be postulated from dated occupations before the first ahu construction and the completed final stage ahu, placed within the existing dated typological sequence of ahu on Easter Island.

We postulate that the remains identified under the foundations of $A h u$ Tongariki architecturally reflect processes of initial fission and territorial expansion of the founding population and a later fusion of sociopolitical units that parallel a significant demographic peak. The monument, as such, is not only the material expression of that process, also reflects the growing complexity and importance of one of the two major segments of population of the island's late prehistory.

Several lineage ahu were rebuilt and joined together to form a larger but irregular altar, which was subsequently recycled. An enormous, well planned, platform was being built on top of this structures to support fifteen or more very large statues, as a final expression of the power, importance and size of the group that occupied the area. Ahu Tongariki probably became the sociopolitical and religious center of the eastern confederacy of 'tribes' described in the ethnographic records available for this period. 


\section{REVISTA DE URBANISMO

http://revistaurbanismo.vchile.cl

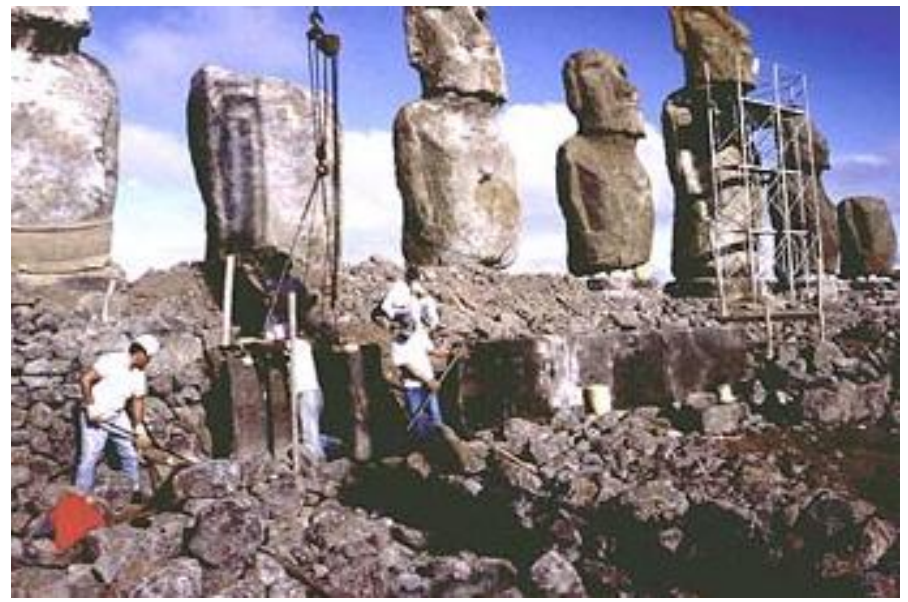

Figura 7. GArchivo Instituto Isla de Pascua, F.A.U. Universidad de Chile.

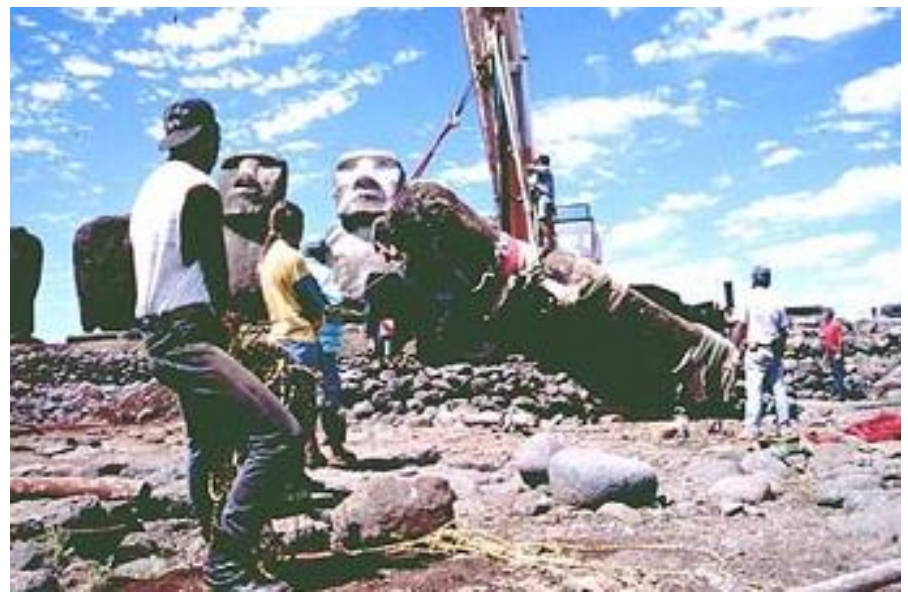

Figura 8. GArchivo Instituto Isla de Pascua, F.A.U. Universidad de Chile.

Research and restoration work at Tongariki between 1992 and 1996 was part of the largest salvage and reconstruction effort carried out in Polynesia. The pertinence and accuracy of the reconstruction of the ruins of the ahu and restoration of the fifteen monolithic statues of volcanic tuff (moai), documented in historic times, will be reported elsewhere.

The condition of post-tsunami remains posed serious difficulties to the precise archaeological control of the reconstruction effort. Nevertheless, as is the demonstrated case with most of other monuments of its kind on the island, the evidence obtained at the site whole site is clearly indicative of clear cultural continuity. 
http://revistaurbanismo.uchile.cl

The first human occupation of the area probably occurred circa 900-1000 AD and predates the first of at least three main ahu constructions. The final monument was the result of a major late architectural expansion that was probably unfinished as a result of the social unrest that characterized the final stages of Easter Island prehistory.- 